\title{
ДОСЛІДЖЕННЯ ДЕЯКИХ ПОКАЗНИКІВ КЛІТИННОГО ІМУНІТЕТУ У ХВОРИХ НА РОЗПОВСЮДЖЕНИЙ ПСОРІАЗ
}

Вступ. Імунні порушення відіграють важливу роль у патогенезі псоріазу. Так, незважаючи на те, що дані імунологічних досліджень досить численні, вони є суперечливими і часом непорівнянними, що, можливо, пов'язано з використанням різних методичних підходів без урахування клінічних особливостей захворювання, стадії процесу, що супроводжує патологію.

Мета дослідження - вивчити деякі показники клітинного імунітету у хворих на розповсюджений псоріаз.

Методи дослідження. Визначено такі показники: Т-лімфроцити (СД3+), Т-лімфоцити хелпери (СД4), T-цитотоксичні клітини (СД8), В-лімфроцити (СД19), фрактор апоптозу (FASx), ендотелеїн-1.

Результати й обговорення. Аналіз стану клітинного імунітету в обстежених хворих на псоріаз свідчить про збільшення, порівняно з умовно-здоровими пацієнтами, вмісту Т-лімфоцитів (СД3 $)$, Т-лімороцитів хелперів (СД4), Т-цитотоксичних клітин (СД8) при прогресивній та стаціонарній стадіях захворювання. Показано, що у хворих із прогресивною стадією загибель клітин вірогідно підвищена. У пацієнтів із прогресивною стадією псоріазу вміст поліпептиду - ендотелеїну-1 збільшений, що вказує, з одного боку, на пошкодження ендотелію судин при псоріазі, а з іншого - на прискорення темпу диференціювання тканин і апоптозу.

Висновок. Отримані дані свідчать про значні зміни показників клітинного імунітету у хворих із прогресивною стадією.

КЛЮЧОВІ СЛОВА: псоріаз; імунітет; апоптоз; Т-лімфоцити; В-лімфоцити; фактор апоптозу; ендотелеїн-1.

ВСТУП. Імунні порушення відіграють важливу роль у патогенезі псоріазу. Вони виникають як на клітинному, так і на гуморальному рівнях, характеризуються зміною вмісту імуноглобулінів, циркулюючих імунних комплексів, пулу лімфроцитів, а також субпопуляцій лімфроцитів на фооні первинних змін клітин як дермального шару, так і епідермісу [1].

Доведено існування двох форм загибелі клітин - некрозу та апоптозу. Основу апоптозу становлять зміни біохімії клітини: активування срерментативних шляхів, виникнення енергетичного дисбалансу, диссрункції мітохондрій, порушення іонного гомеостазу та орізико-хімічних властивостей клітинних мембран. Фактично апоптоз розглядають як механізм, за допомогою якого відбувається елімінація пошкоджених і чужорідних клітин, а також клітин 3 генетично дефектним апаратом [2, 3]. Якщо стан епідермісу при псоріазі $€$ відображенням трьох орундаментальних процесів, що перебігають у кератиноцитах, - проліферації, диференціювання та (с А. Л. Загайко, Л. В. Галузінська, 2017. апоптозу, то можна припустити здійснення запуску апоптозу за допомогою активованих Т-клітин, на яких експресується FAS-ліганд, поєднаний із FAS-рецептором, що, у свою чергу, експресується на кератиноцитах тільки пошкодженого епідермісу. При псоріазі, за даними багатьох досліджень, головним $€$ порушення взаємодії Т-клітин і кератиноцитів внаслідок зменшення кількості стовбурових кератиноцитів, що не беруть участі в активному життєвому циклі при збільшенні кількості активнопроліфееруючих кератиноцитів, апоптична загибель яких дуже знижена. У результаті вказаних процесів розвивається гіперпролісрерація кератиноцитів, що й зумовлює появу на шкірі хворих папул і бляшок [4].

Так, незважаючи на те, що дані імунологічних досліджень досить численні, вони є суперечливими і часом непорівнянними, що, можливо, пов'язано з використанням різних методичних підходів без урахування клінічних особливостей захворювання, стадії процесу, що супроводжує патологію. Більшість дослідників спостерігала 
порушення в Т-клітинній ланці імунітету, що найчастіше визначається зниженням рівня абсолютного і відносного вмісту Т-лімфроцитів, а саме Т-хелперів (CD4), на фроні підвищення або зниження кількості Т-супресорів (CD8), а також зменшенням співвідношення CD4/CD8 порівняно зі здоровими особами. Зменшення вмісту в периферичній крові Т-лімфоцитів, зокрема Т-хелперів, можна пояснити їх накопиченням у псоріатичних осередках, а Т-супресорну недостатність розглядають як провідну ланку в патогенезі захворювання. Активація Т-лімфроцитів хелперів (CD4) індукує ряд імунологічних реакцій, у тому числі активацію макрофрагів, що синтезують широкий спектр прозапальних медіаторів, насамперед цитокінів, таких, як ФНП- $\alpha$, ІЛ-18 та ІЛ-1ß [5]. Особливий науковий інтерес викликає сорормульована в останні роки концепція, згідно з якою при псоріатичній хворобі фрормуються цитокінозалежні патогенетичні механізми з участю ІЛ-1ß, ФНП- $\alpha$, ІЛ-6, ІЛ-18 [6]

Мета дослідження - вивчити деякі показники клітинного імунітету у хворих на розповсюджений псоріаз.

МЕТОДИ ДОСЛІДЖЕННЯ. Обстежених поділили на три групи: 1-ша - хворі з прогресивною стадією псоріазу (116 людей); 2-га - пацієнти зі стаціонарною стадією (16 людей); 3-тя - контроль, умовно-здорові (26 людей). Одноразово всім особам було проведено забір крові та визначено такі показники: кількість Т-лімсроцитів $\left(С Д 3^{+}\right)$, Т-лімфоцитів хелперів (СД4), Т-цитотоксичних клітин (СД8), В-лімсроцитів (СД19), вміст фрактора апоптозу (FASx), ендотелеїну-1.

Усі отримані результати досліджень обробляли з використанням програми Statistica 5,0 for Windows для ПК. Статистичну обробку резуль- татів проведених досліджень здійснено за допомогою коефіцієнтів Стьюдента (t) і ВілкоксонаМанна-Уїтні (w).

РЕЗУЛЬТАТИ Й ОБГОВОРЕННЯ. АНаліЗ стану клітинного імунітету в обстежених хворих на псоріаз свідчить про збільшення, порівняно з умовно-здоровими пацієнтами, вмісту Т-лімфроцитів (СД3 ${ }^{+}$), Т-лімфроцитів хелперів (СД4), Т-цитотоксичних клітин (СД8) при прогресивній та стаціонарній стадіях захворювання (табл.).

Порівняльний аналіз показників клітинного імунітету у хворих на псоріаз залежно від стадії перебігу не виявив вірогідних відмінностей у показниках між прогресивною та стаціонарною стадіями перебігу хвороби. Щодо фрактора апоптозу (FASx), який характеризує запрограмовану загибель клітин, то встановлено, що у хворих із прогресивною стадією загибелі клітин його концентрація була вірогідно підвищена, тоді як у пацієнтів із стаціонарною стадією вона вірогідно не відрізнялася від відповідного показника осіб контрольної групи (табл.).

У хворих із прогресивною стадією псоріазу виявлено підвищений вміст поліпептиду - ендотелеїну-1 (складається 321 амінокислотного залишку; присутній у плазмі крові в трьох ізофрормах - ЕT-1, ЕT-2, ЕТ-3) (табл.). Зростання рівня ЕТ-1 вказувало, з одного боку, на пошкодження ендотелію судин при псоріазі, а з іншого - на прискорення темпу дифреренціювання тканин і апоптозу.

Дослідження апоптозу у хворих на розповсюджений псоріаз залежно від клінічних проявів, стадії і сезонності перебігу, а також від типу вищої нервової діяльності та соматотипів показали різну його спрямованість. Так, залежно від клінічних варіантів перебігу псоріазу апоптоз віро-

Таблиця - Показники клітинного імунітету у хворих на розповсюджений псоріаз залежно від стадії перебігу

\begin{tabular}{|c|c|c|c|c|c|c|}
\hline \multirow[b]{2}{*}{ Показник } & \multicolumn{2}{|c|}{ Прогресивна стадія } & \multicolumn{2}{|c|}{ Стаціонарна стадія } & \multicolumn{2}{|c|}{ Контрольна група } \\
\hline & $\begin{array}{l}\text { кількість } \\
\text { хворих }\end{array}$ & $M \pm m$ & $\begin{array}{l}\text { кількість } \\
\text { хворих }\end{array}$ & $M \pm m$ & $\begin{array}{l}\text { кількість } \\
\text { осіб }\end{array}$ & $\mathrm{M} \pm \mathrm{m}$ \\
\hline Т-лімфоцити (СДЗ $\left.3^{+}\right)$пкг/мл & 121 & $\begin{array}{c}2450,22 \pm \\
39,78^{3}\end{array}$ & 16 & $\begin{array}{c}2424,20 \pm \\
51,51^{3}\end{array}$ & 26 & $\begin{array}{l}869,30 \pm \\
16,65^{1,2}\end{array}$ \\
\hline $\begin{array}{l}\text { Т-лімфроцити хелпери (СД4), } \\
\text { пкг/мл }\end{array}$ & 121 & $\begin{array}{l}767,43 \pm \\
59,84^{3}\end{array}$ & 16 & $\begin{array}{c}764,68 \pm \\
38,72^{3}\end{array}$ & 26 & $\begin{array}{l}325,27 \pm \\
11,18^{1,2}\end{array}$ \\
\hline $\begin{array}{l}\text { Т-цитотоксичні клітини (СД8), } \\
\text { пкг/мл }\end{array}$ & 121 & $\begin{array}{c}886,68 \pm \\
23,23^{3}\end{array}$ & 16 & $\begin{array}{c}876,45 \pm \\
23,97\end{array}$ & 26 & $\begin{array}{l}284,92 \pm \\
14,38^{1,2}\end{array}$ \\
\hline В-лімфроцити (СД19), пкг/мл & 121 & $\begin{array}{c}664,90 \pm \\
21,83^{3} \\
\end{array}$ & 16 & $\begin{array}{c}662,31 \pm \\
28,30 \\
\end{array}$ & 26 & $\begin{array}{l}238,68 \pm \\
17,48^{1,2} \\
\end{array}$ \\
\hline Фактор апоптозу (FASx), пкг/мл & 121 & $\begin{array}{l}428,22 \pm \\
40,71^{2,3}\end{array}$ & 16 & $\begin{array}{l}4,93 \pm \\
4,12^{1}\end{array}$ & 26 & $\begin{array}{l}3,63 \pm \\
0,78^{1}\end{array}$ \\
\hline Ендотелеїн-1, пкг/мл & 121 & $\begin{array}{l}817,09 \pm \\
55,96^{2,3}\end{array}$ & 16 & $\begin{array}{c}17,38 \pm \\
2,19^{1} \\
\end{array}$ & 14 & $\begin{array}{l}8,04 \pm \\
2,06^{1,2}\end{array}$ \\
\hline
\end{tabular}

Примітка. ${ }^{1}$ - вірогідно відрізняється від показників хворих із прогресивною стадією; ${ }^{2}$ - вірогідно відрізняється від показників пацієнтів із стаціонарною стадією; ${ }^{3}$ - вірогідно відрізняється від показників осіб контрольної групи. 
гідно підвищувався в пацієнтів із крупнобляшковим, ексудативним та бляшковим псоріазом порівняно $з$ хворими на краплеподібний псоріаз. Дослідження залежно від стадії перебігу захворювання дозволили виявити вірогідне підвищення апоптозу у хворих лише 3 прогресивною стадією порівняно з практично здоровими особами. У пацієнтів із стаціонарною стадією цей показник мав тільки тенденцію до зростання і вірогідно не відрізнявся від показника осіб контрольної групи. Ці дані дають підставу розглядати високий рівень апоптозу при прогресивній стадії перебігу псоріазу як один із важливих механізмів його патогенезу. Залежно від сезонності перебігу результати досліджень показали вірогідне зниження апоптозу у хворих із літнім типом перебігу порівняно з відповідним показником у пацієнтів із зимовим типом та хворих 3

\section{СПИСОК ЛІТЕРАТУРИ}

1. Смирнова С. В. Клинико-иммунологические особенности псориаза / С. В. Смирнова, М. В.Смольникова, В. Ю. Райкова // Цитокины и воспаление. 2010. - 9, № 4. - С. 121-122.

2. Айвазян А. А. Псориаз - иммунозависимое заболевание / А. А. Айвазян // Эксперим. и клинич. дерматокосметология. - 2014. - № 2. - С. 36-38.

3. Nestle F. O. Psoriasis / F. O. Nestle, D. H. Kaplan, J. Barker // Engl. J. Med. - 2009. - 361. - P. 496-509

4. Андрашко Ю. В. Современная модель иммунопатогенеза псориаза: пути эффеектиного воздей- перебігом процесу, при якому відмічали втрату сезонності. Дослідження залежно від типу вищої нервової діяльності дозволили виявити різницю даних між меланхоліками та фрлегматиками, вони були вірогідно вищими в меланхоліків. Залежно від соматотипів встановлено відмінність процесів апоптозу між нормостеніками та астеніками, гіперстеніками й астеніками, при цьому в астеніків показники апоптозу вірогідно знижувались порівняно з нормостеніками і гіперстеніками.

ВИСНОВОК. Отримані дані свідчать про значні зміни показників клітинного імунітету у хворих із прогресивною стадією, коли з'являються нові міліарні папули й еритематозна облямівка по краю папул не вкрита лусочками, коли спостерігаються ріст бляшок по периферії, позитивний симптом Кебнера, якщо на місці травми виникають нові висипання.

ствия / Ю. В. Андрашко // Дерматолог. - 2011. - 2 № 1. - C. 99-101.

5. Dinarello C. A. Interleukin-18 and the pathogenesis of inflammatory diseases / C. A. Dinarello // Semin. Nephrol. - 2007. - 27, N 1. - P. 98-114.

6. Хобейш М. М. Современные аспекты иммунопатогенеза и лечения псориаза / М. М. Хобейш, Е. В. Соколовский // Совр. пробл. дерматовенерологии, иммунологии и врачебной косметологии. - 2011. № 5. - С. 56-60.

\section{REFERENCES}

1. Smirnova, S.V., Smolnikova, M.V., \& Raykov, V.Yu. (2010). Kliniko-immunologicheskie osobennosti psoriaza [Clinical and immunological features of psoriasis]. Tsytokiny $i$ vospalenie - Cytokines and Inflammation, 9 (4), 121-122 [in Russian].

2. Ayvazyan, A.A. (2014). Psoriasis - an immune dependent disease. Experimental and Clinical Dermatocosmetology, 2, 36-38.

3. Nestle, F.O., Kaplan, D.H., \& Barker J. (2009). Psoriasis. Engl. J. Med., 361, 496-509.

4.Andrashko, Yu.V. (2011). Sovremennaya model immunopatogeneza psoriaza: puti effektivnogo vozdey- stviya [Modern model of immunopathogenesis of psoriasis: ways of effective influence]. Dermatolog Dermatologist, 2 (1), 99-101 [in Russian].

5. Dinarello, C.A. (2007). Interleukin-18 and the pathogenesis of inflammatory diseases. Semin. Nephrol., 27 (1), 98-114.

6. Hobeysh, M.M., \& Sokolovskiy E.V. (2011). Sovremennye aspekty immunopatogeneza i lecheniya psoriaza [Contemporary aspects of the immunopathogenesis and treatment of psoriasis]. Sovr. probl. dermatovenerologii, immunologii i vrachebnoy kosmetologii - Modern Problems of Dermatovenerology, Immunology and Medical Cosmetology, 5, 56-60 [in Russian]. 


\section{ИССЛЕДОВАНИЯ НЕКОТОРЫХ ПОКАЗАТЕЛЕЙ КЛЕТОЧНОГО ИММУНИТЕТА У БОЛЬНЫХ РАСПРОСТРАНЕННЫМ ПСОРИАЗОМ}

\section{Резюме}

Вступление. Иммунные нарушения играют важную роль в патогенезе псориаза. Так, несмотря на то, что данные иммунологических исследований весьма многочисленны, они являются противоречивыми и порой несравнимыми, что, возможно, связано с использованием различных методических подходов без учета клинических особенностей заболевания, стадии процесса, что сопровождает патологию.

Цель исследования - изучить некоторые показатели клеточного иммунитета у больных распространенным псориазом.

Методы исследования. Определены следующие показатели: Т-лимфоциты (СДз+), Т-лимфоциты хелперы (СД4), Т-цитотоксические клетки (СД8), В-лимфоциты (СД19), фрактор апоптоза (FASx), эндотелеин-1.

Результаты и обсуждение. Анализ состояния клеточного иммунитета у обследованных больных псориазом свидетельствует об увеличении, в сравнении с условно-здоровыми пациентами, содержания Т-лимфроцитов (СДЗ'), Т-лимфроцитов хелперов (СД4), Т-цитотоксических клеток (СД8) при прогрессивной и стационарной стадиях заболевания. Показано, что у больных с прогрессивной стадией гибель клеток достоверно повышена. У пациентов с прогрессивной стадией псориаза содержание полипептида - эндотелеина-1 увеличено, что указывает, с одной стороны, на повреждение эндотелия сосудов при псориазе, а с другой - на ускорение темпа дифрореренцировки тканей и апоптоза.

Вывод. Полученные данные свидетельствуют о значительных изменениях показателей клеточного иммунитета у больных с прогрессивной стадией.

КЛЮЧЕВЫЕ СЛОВА: псориаз; иммунитет; апоптоз; Т-лимфоциты; В-лимфоциты; фрактор апоптоза; эндотелеин-1.

A. L. Zagayko, L. V. Galuzinska NATIONAL UNIVERSITY OF PHARMACY, KHARKIV

\section{INVESTIGATION OF SOME INDICES OF CELLULAR IMMUNITY IN PATIENTS WITH COMMON PSORIASIS}

\section{Summary}

Introduction. Immune disorders play an important role in the pathogenesis of psoriasis. So, despite the fact that the data of immunological studies are very numerous, they are sometimes contradictory and not comparable, which is probably connected with the use of different methodological approaches, without taking into account clinical features of the disease, stage of the process, accompanied by a pathology.

The aim of the work - to investigate some parameters of cellular immunity in patients with common psoriasis.

Research Methods. The following indices: content of T-lymphocytes (CD 3+) T-lymphocytes helper cells (CD4), $T$ cytotoxic cells (CD8), B lymphocytes (CD 19), the factor of apoptosis FASx, endotheline-1 were measured.

Results and Discussion. Analysis of cellular immunity in patients with psoriasis indicates an increase, when compared with healthy patients, T-lymphocytes (BG3+) T-lymphocytes helper cells (CD4), T cytotoxic cells (CD8), with progressive and inpatient stages of the disease. It was found that patients in the progressive stage of cell death significantly increased. In patients with progressive stage of psoriasis revealed an increased content of polypeptideendothelin that indicates, on the one hand, the violation of vascular endothelium in psoriasis, and on the other, rate of tissue differentiation and apoptosis.

Conclusions. The data obtained indicate significant changes of parameters of cellular immunity in patients with advanced stage.

KEY WORDS: psoriasis; immunity; apoptosis; T-lymphocytes; B-lymphocytes; apoptosis factor; endotheline-1.

Отримано 27.04.17

Адреса для листування: Л. В. Галузінська, вул. Куликівська, 12, Харків, 61002, Україна, e-mail: Ijubvgaluzinskaja@mail.ua. 